\title{
Orbital Eosinophilic Granuloma in a Child: A Case Report
}

\section{Çocukta Orbital Eozinofilik Granüloma: Bir Olgu Sunumu}

\author{
Gokmen KAHILOGULLARI ${ }^{1}$, Hakan TUNA ${ }^{1}$, Isinsu KUZU², Agahan UNLU ${ }^{1}$ \\ ${ }^{1}$ Ankara University, Faculty of Medicine, Department of Neurosurgery, Ankara, Turkey \\ ${ }^{2}$ Ankara University, Faculty of Medicine, Department of Pathology, Ankara, Turkey
}

Corresponding Author: GOKMEN KAHILOGULLARI / E-mail: gokmenkahil@hotmail.com

\begin{abstract}
Eosinophilic granuloma is a rare disease belonging to the Langerhans' cell histiocytosis group. It accounts for only $1 \%$ of all tumor-like lesions of bone. A 6-year-old girl presented with proptosis, and a mass and pain in her right eye. Cranial computerized tomography and magnetic resonance imaging revealed a mass in her right orbital area. The patient was operated through a right frontotemporal craniotomy and orbitozygomatic osteotomy. The tumour was totally removed. The postoperative course was uneventful. Histopathological examination revealed a diagnosis of eosinophilic granuloma with typical Langerhans cells and eosinophylic leucocyte infiltration. We report an orbital eosinophilic granuloma case, which is rarely seen, and discuss its clinical and pathological features.
\end{abstract}

KEYWORDS: Eosinophilic granuloma, Orbital tumour, Child

öz

Eozinofilik granüloma, Langerhans hücreli histiositozis grubunda yer alan nadir bir hastalıktır. Kemiğin tümöre benzer lezyonlarının yalnızca \%1'ini oluşturur. Altı yaşında bir kız çocuk, sağ gözde proptozis ve kitle ile sağ gözde ağrı şikâyetleriyle kliniğe başvurdu. Kranial tomografi ve magnetik rezonans görüntülemede sağ orbital bölgede kitle tespit edildi. Hasta sağ frontotemporal kraniotomi ve orbitozigomatik osteotomi ile opere edildi. Kitle total olarak çıkarıldı. Hastada operasyon sonrası herhangi bir komplikasyon gelişmedi. Histopatolojik tanı değerlendirmesi tipik Lagerhans hücreleri ve eozinofilik lökosit infiltrasyonu ile birlikte eozinofilik granülom olarak geldi. Çalışmamızda, orbital bölgenin çok nadir görülen bir tümörü olan eozinofilik granüloma olgusu klinik ve patolojik özellikleri ile sunuldu.

ANAHTAR SÖZCÜKLER: Eozinofilik granülom, Orbital tümör, Çocuk

\section{INTRODUCTION}

Eosinophilic granuloma (EG) is a disease belonging to the Langerhans' cell histiocytosis (LCH) group, like Hand-SchullerChristian disease and Letterer-Siwe disease. This group of diseases is characterized by an abnormal proliferation of histiocyte-forming granulomas $(1,5)$. Eosinophilic granuloma is a relatively rare disease and accounts for only $1 \%$ of all tumour-like lesions of bone $(4,9,12)$. EG is the most benign and most common variant of $\mathrm{LCH}$. It may occur at any age and the skull is the most frequent site of involvement $(3,8)$. Involvement of the orbit is uncommon and has been a subject of dispersed case reports or small clinical series.

\section{CASE REPORT}

A 6-year-old girl was admitted to our department with a brief history of pain, proptosis and mass in her right eye. Physical examination revealed a palpable $3 \times 3 \mathrm{~cm}$ tender mass over the lateral orbital wall. Her right eye was slightly proptotic. The extra ocular movements were full. She had no palpable adenopathy. The abdomen was not tender and had no palpable mass. Her neurological examination was intact. Her chest $x$-ray was normal, and there were no other bony lesions on skeletal $x$-rays including the skull. A computed tomographic (CT) scan of the orbits and head with contrast enhancement revealed a $3 \mathrm{~cm}$ enhancing, destructive soft tissue mass centred in the lateral wall of the right orbit and reached its apex (Figure 1A). The mass was also extending into the infratemporal fossa and into the anterior portion of the middle cranial fossa. Magnetic resonance imaging (MRI) demonstrated a mass filling the lateral wall of the orbit on the right extending into the orbital apex, infratemporal fossa, and anterior part of the middle cranial fossa. It was isointense compared with brain parenchyma on T1-weighted imaging, proton density-weighted imaging, and T2-weighted imaging. After intravenous administration of contrast, the mass showed a well degree of enhancement (Figure 1B).

The patient underwent a right fronto-temporal craniotomy with additional orbito-zygomatic osteotomy. The tumour was well-circumscribed, non-encapsulated, and pale grey in color. There was no evidence of dural infiltration by the tumour in the middle fossa. The tumour was resected totally and postoperative course was uneventful. Histopathological examination revealed the diagnosis of eosinophilic granuloma with typical Langerhans cells and eosinophylic leucocyte 


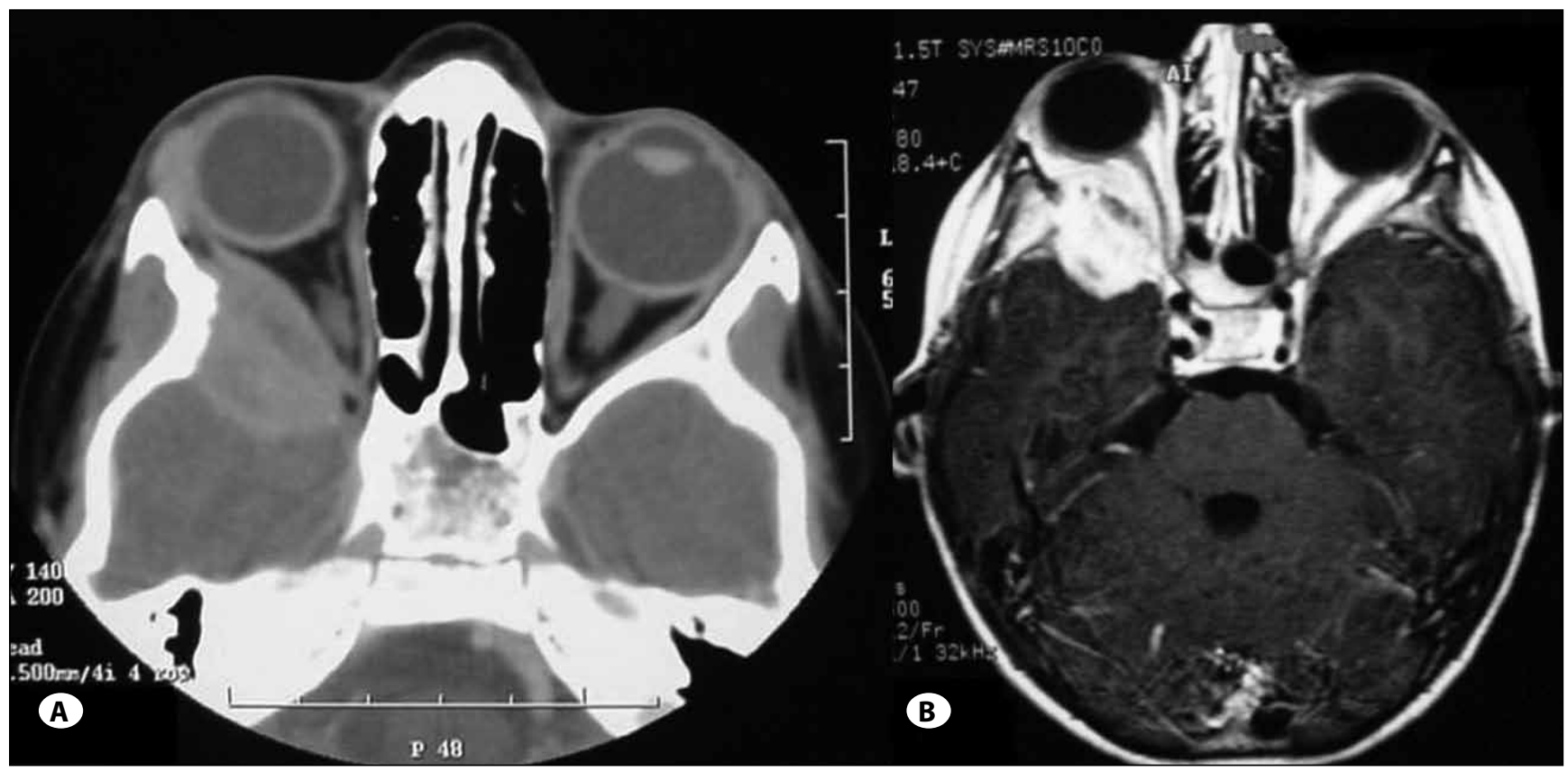

Figure 1: On the CT scan, a soft tissue mass had destroyed the posterior part of lateral wall of the right orbit (A). In T1-weighted images obtained after contrast enhancement, a soft tissue mass with good enhancement, centred in the lateral wall of the right orbit and reached its apex $\mathbf{( B )}$.
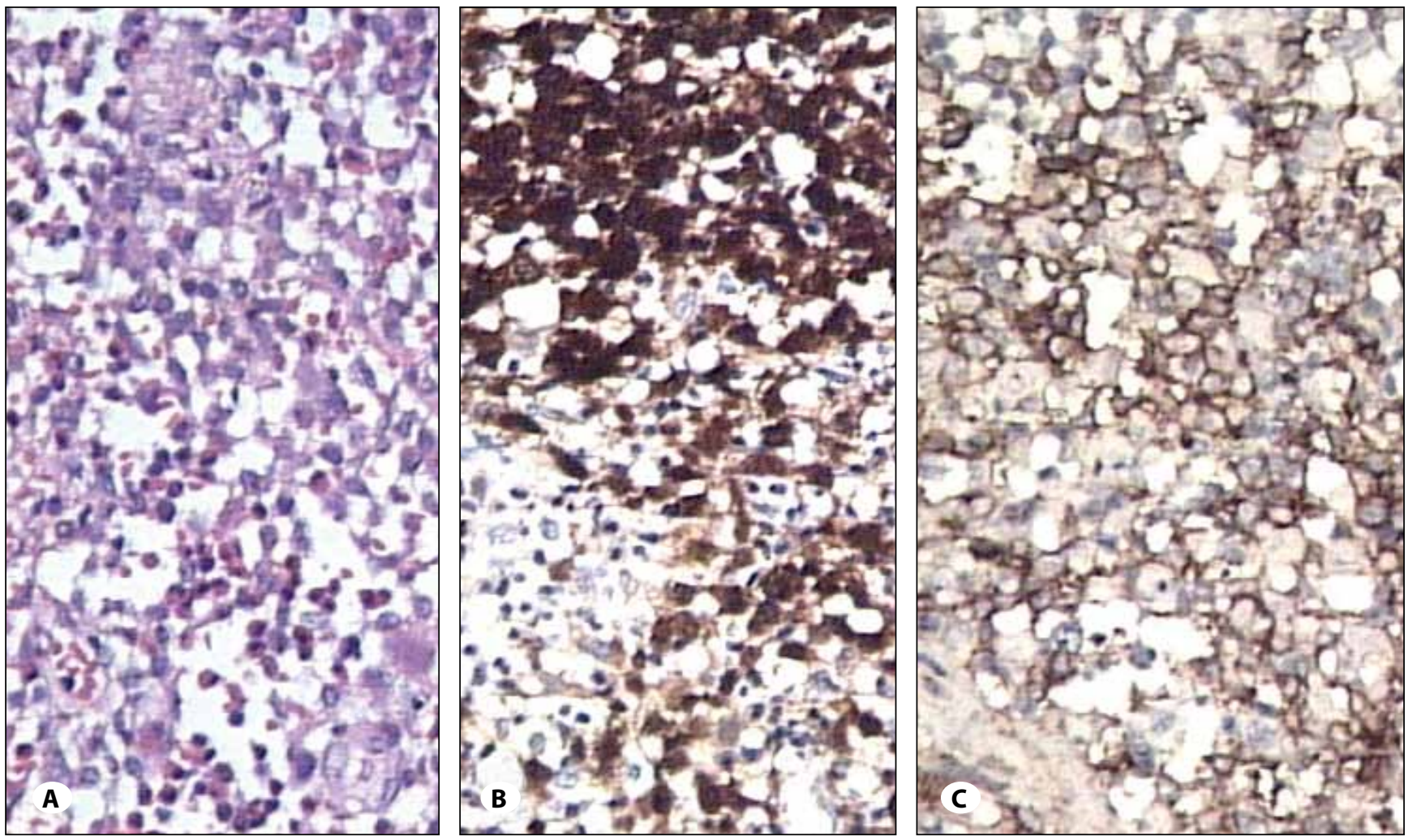

Figure 2: Routine histopathological diagnosis was straightforward with typical Langerhans cells and eosinophilic leucocyte infiltration (A). The infiltrating cells stained strongly with S-100 (B) and CD 1a (C). 
infiltration. The origin of the infiltrating cells was confirmed by their strong positivity with S-100 and CD 1a (Figure 2A-C). There was no evidence of recurrence on her follow-up orbital $\mathrm{MRI}$ in the postoperative sixth month.

\section{DISCUSSION}

Eosinophilic granuloma is a disease from a group of diseases termed Histiocytosis-X. Histiocytosis refers to spectrum of uncommon proliferative disorders of Langerhans cells. Langerhans cells are a component of the mononuclear phagocyte system derived from precursor cells in the bone marrow. They are found in the epidermis and in the other sites such as the lymph nodes, spleen, thymus, and mucosal tissues. Langerhans cells ingest, process, and present antigens to T-lymphocytes. Histiocytosis- $X$ is a specific inflammatory histiocytosis with no known cause and may represent an atypical immunological reaction or an unusual manifestation of an autoimmune disorder (6). Histiocytosis- $X$ is rare, occurring most commonly in children with 0.6 cases per million children under 15 years of age $(1,9)$. Ophthalmological manifestations are seen in about $10 \%$ of cases. Histiocytosis- $X$ is an uncommon cause of orbital tumour and it represents 1 to $7 \%$ of paediatric orbital tumours in large clinical series $(4,9,12)$. Orbital histiocytosis is generally seen in children with 1 to 4 years of age (9). Most of the patients in the literature are children, and the orbital lesion usually arises in bone, originating from the infero-lateral orbital wall, as was in our case. Historically, diagnosis has been made by noting an irregular contour, lytic'punched-out' defect with hyperostosis of the edges of the lesion on a plain film (2). CT and MRI are valuable diagnostic studies to define the margins of the tumour before the treatment and to select the treatment modality (6). When interpreting such an orbital lesion on CT or MRI, dermoid cyst, primary bone tumours such as osteosarcoma, aneurismal bone cyst, ossifying fibroma, rhabdomyosarcoma, juvenile fibrosarcoma, aggressive fibromatosis, lacrimal gland tumours, leukemic infiltration, granulocytic sarcoma or chloroma, sinus histiocytosis, metastatic neuroblastoma, metastatic Wilm's tumour, and metastatic Ewing's sarcoma should be kept in mind for differential diagnosis $(1,6,9)$.

The treatment of Histiocytosis- $X$ consists of biopsy and followup, low-dose local irradiation, cytotoxic agents, steroids, and surgical curettage and excision $(5,7,12)$. In such patients, the roles of various treatment options, namely surgical excision, biopsy alone, radiation therapy, systemic chemotherapy, and conservative follow-up, have not been well established. Although surgical excision has been advocated as the primary mode of therapy for treating patients with orbital EG, the role of an aggressive surgical approach has not been well documented (10). On the other hand, spontaneous regression of orbital histiocytosis has been described in the literature $(4,11)$.

\section{CONCLUSION}

Orbital eosinophilic granuloma is a rare type of tumour. Nonetheless, it should be included in the differential diagnosis of orbital tumours, especially when the tumour is presumed to be bone-originated. It is important for surgeons to be conscious of Histiocytosis- $X$ in the orbit and be familiar with the course of the disease. To achieve proper diagnosis and management of disease, differentiation of multi-systemic and localised disease is vital.

\section{REFERENCES}

1. Castillo BV Jr, Kaufman L: Paediatric tumours of the eye and orbit. Pediatr Clin North Am 50:149-172, 2003

2. David $R$, Oria $R A$, Kumar $R$, Singleton $E B$, Lindell $M M$, Shirkhoda A, Madewell JE: Radiologic features of eosinophilic granuloma of bone. AJR Am J Roentgenol 153:1021-1026, 1989

3. Fujimura $M$, Nishijima $M$, Umezawa $K$, Hayashi T, Kaimori $M$ : A case of calvarial eosinophilic granuloma with rapid expansion and wide skull invasion: Immunohistochemical analysis of Ki-67. J Clin Neurosci 9:72-76, 2002

4. Glover AT, Grove AS Jr: Eosinophilic granuloma of the orbit with spontaneous healing. Ophthalmology 94:1008-1012, 1987

5. Harbour JW, Char DH, Ljung BM, Luna-Fineman S: Langerhans cell histiocytosis diagnosed by fine needle biopsy. Arch Ophthalmol 115:1212-1213, 1997

6. Hidayat AA, Mafee MF, Laver NV, Noujaim S: Langerhans' cell histiocytosis and juvenile xanthogranuloma of the orbit. Clinicopathologic, CT, and MR imaging features. Radiol Clin North Am 36:1229-1240, 1998

7. Kindy-Degnan NA, Laflamme P, Duprat G, Allaire GS: Intralesional steroid in the treatment of an orbital eosinophilic granuloma. Arch Ophthalmol 109:617-618, 1991

8. Kramer TR, Noecker RJ, Miller JM, Clark LC: Langerhans cell histiocytosis with orbital involvement. Am J Ophthalmol 124:814-824, 1997

9. Rootman J: Diseases of the orbit. Philadelphia: J.B.Lippincott Company, 1988:231-236

10. Shields JA, Bakewell B, Augsburger JJ, Donosa LA, Bernardino V: Space-occupying orbital masses in children. A review of 250 consecutive biopsies. Ophthalmology 93:379-384, 1986

11. Smith JH, Fulton L, O'Brien JM: Spontaneous regression of orbital Langerhans cell granulomatosis in a three-year-old girl. Am J Ophthalmol 128:119-121, 1999

12. Stefanyszyn MA, Handler SD, Wright JE: Pediatric orbital tumors. Otolaryngol Clin North Am 21:103-118, 1988 